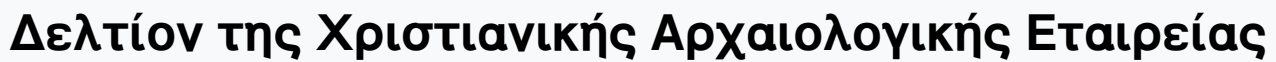

Tó 34 (2013)

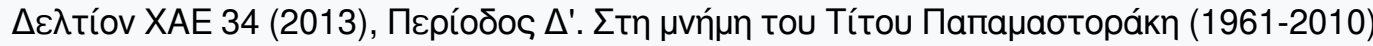

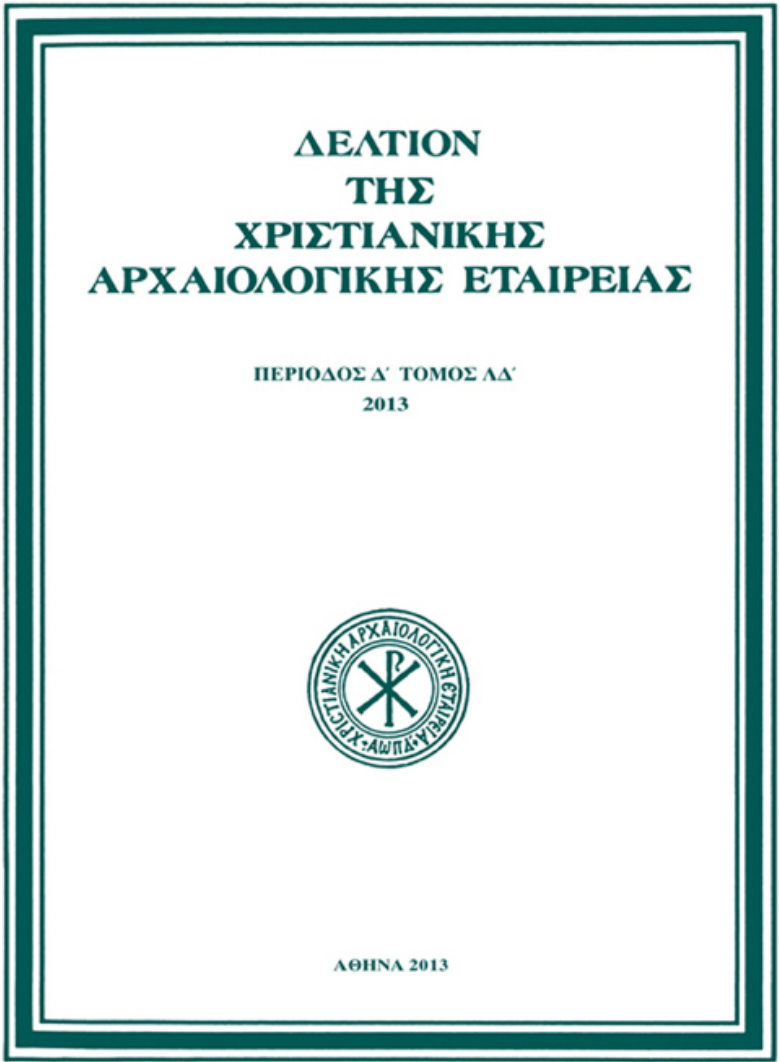

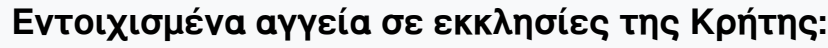

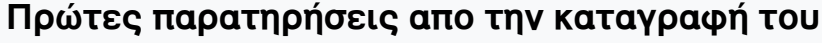

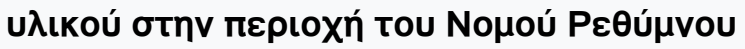

Anastasia G. YANGAKI

doi: $10.12681 /$ dchae.1733

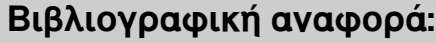

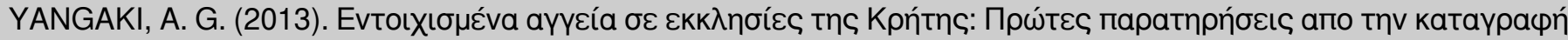

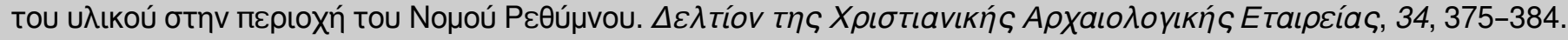
https://doi.org/10.12681/dchae.1733 


\author{
Anastasia G. Yangaki
}

\title{
IMMURED VESSELS IN CHURCHES ON CRETE: PRELIMINARY OBSERVATIONS ON MATERIAL FROM THE PREFECTURE OF RETHYMNON*
}

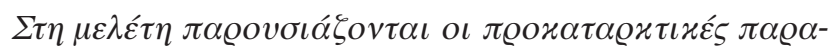

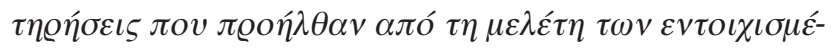

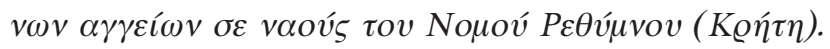

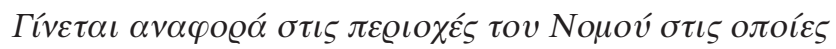

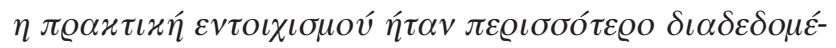

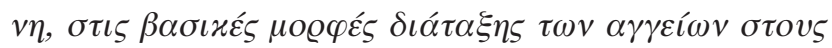

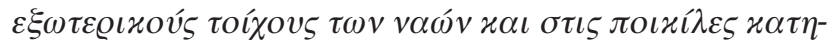

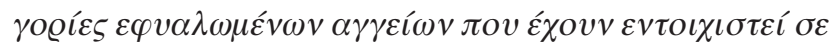
$\alpha v \tau o u ́ s$.

In the territories of what is now Greece, the exterior walls of an important number of churches from the midand late Byzantine periods are decorated with immured

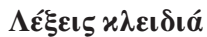

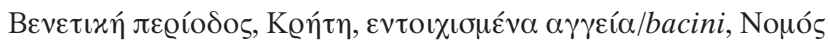
Peधúuvov.
The article presents the preliminary observations deriving from the study of immured vessels in churches of the Prefecture of Rethymnon (Crete). Mention is made of the areas where this practice finds its largest diffusion, of the main forms of distribution of the vessels on the façades of churches, of the different categories of glazed wares used as bacini.

vessels, ${ }^{1}$ the so-called bacini, and their study has already attracted the interest of a number of scholars. ${ }^{2}$ In Italy, too, numerous studies are devoted to the study of bacini. ${ }^{3}$

\section{Keywords}

Venetian period, Crete, immured vessels/bacini, Prefecture of Rethymnon.

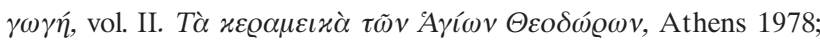

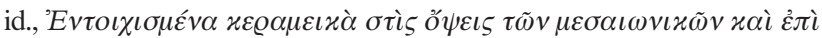

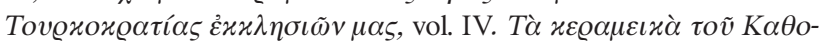

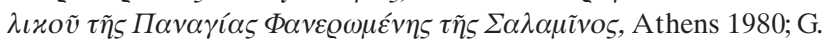

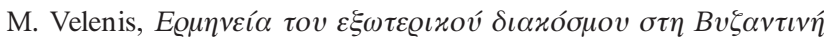

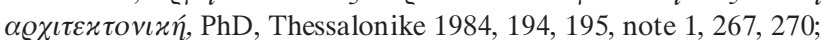

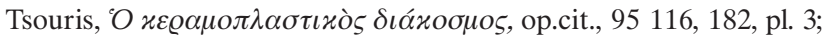

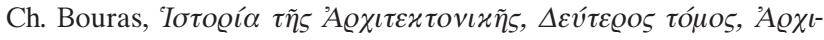

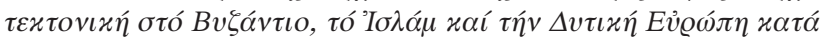

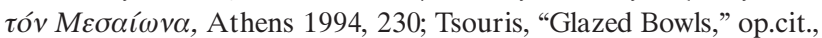

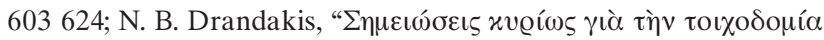

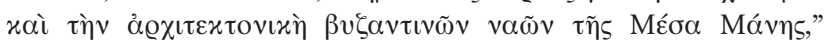
$\Lambda \alpha x \Sigma \pi$ ov $\delta 15$ (2000), 281315.

${ }^{3}$ There are numerous related studies. Illustrative examples would in clude: G. Berti L. Tongiorgi, I bacini ceramici medievali delle chiese di Pisa, Roma 1981; G. Berti E. Tongiorgi, "Per lo studio dei bacini delle chiese di Pisa: Rassegna di recenti contributi alla storia della ce ramica," Le ceramiche medievali delle chiese di Pisa. Contributo per una migliore comprensione delle loro caratteristiche del loro signi- 
These studies have brought to light a lot of information on the history of the monuments in question and the areas in which they are located. They have also added to our knowledge of Mediaeval glazed pottery, thus proving the importance of research of this kind.

Turning to the churches on Crete, although a few researchers, first among them G. Gerola, ${ }^{4}$ had already by the early 20th century noted the existence of immured vessels in a number of the island's churches, a systematic and thorough survey had yet to be made. An initial, more systematic cataloguing ${ }^{5}$ of those Cretan churches whose decoration includes immured vessels reveals that the practice was especially widespread on the island during the period of Venetian rule. This led to the collaboration of the Institute of Historical Research of the National Hellenic Research Foundation with the 28th and the 13th Ephorates of Byzantine Antiquities on the task of recording the relevant data. ${ }^{6}$

The research programme initially focused on the Prefecture of Rethymnon. References in the current scholarship to churches with this form of decoration were combined with an examination of the photographic archive of the 28th Ephorate of Byzantine Antiquities and with systematic on-site research carried out by the author in collaboration with colleagues from the Ephorate. As a result, 74

ficato quale documento di storia, Pisa 1983, 37 79; G. Berti, "Bacini ceramici e strutture architettoniche medievali. Considerazioni basate su una ricerca in Toscana," Atti del I Colloquio Hispano-italiano di archeologia medievale (Granada, Aprile 1990), Granada 1992, 133 172; G. Berti S. Gelichi, "La ceramica bizantina nelle ar chitetture dell'Italia Medievale," La ceramica nel mondo Bizantino tra X e XV secolo e i suoi rapporti con l'Italia (ed. S. Gelichi), Firen ze 1993, 173 174; Atti. XXVI Convegno Internazionale della Ceramica, "I Bacini murati medievali. Problemi e stato della ricerca" (Albisola, 2830 maggio 1993), Firenze 1996.

${ }^{4}$ G. Gerola, Monumenti Veneti nell'Isola di Creta, vol. 2, Venezia

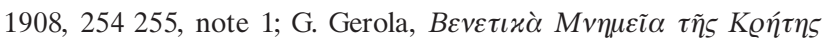

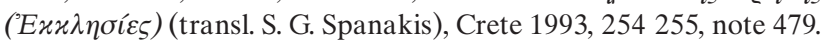
Other researchers who mention the existence of bacini include: K. E.

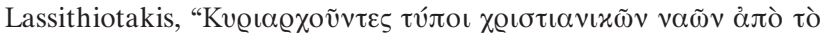

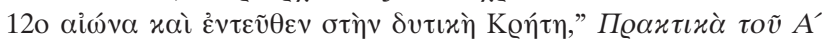

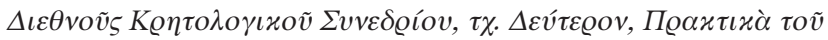

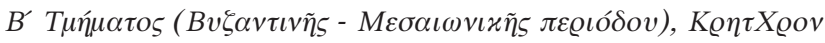

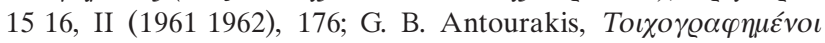

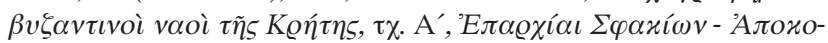

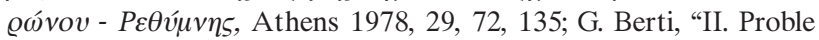
matiche relative allo studio dei Bacini," in S. Gelichi G. Berti S. Nepoti, "Relazione introduttiva sui Bacini," Atti. XXVI Convegno Internazionale della Ceramica, op.cit. (n. 3), 16 20, figs 12 16; M.

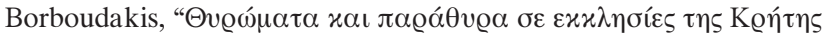

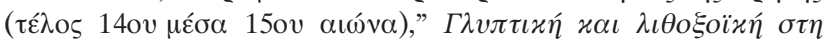

churches (Table 1) were ultimately located with vessels immured in their external wall-faces; there were only fifteen known examples prior to the programme. The identification of an additional 59 churches with immured vessels was also partially the result of restoration work being conducted by the 28th Ephorate. Thus, the removal of plaster from church walls often revealed the existence of immured vessels or empty niches designed for such vessels, which had not previously been visible. Examples of vessels discovered in this way include those found in the katholikon at Chalepa monastery and the neighbouring church of St. Marina, the katholikon of the Asomaton monastery, the church of St. Nicholas in Apostoloi, and the church of St. Nicholas in Labiotes. In other cases, such as the church of Sts Apostles in Petrohori, the vessels themselves had been entirely covered in plaster prior to the restoration work.

Given the size of the area in question, 74 is quite a large number of churches, especially when compared with the number of churches with immured vessels currently known in mainland Greece. While exploring the origins of this form of decoration, the scholars noted its parallel presence in the territories of what is now Greece and on the Italian peninsula. ${ }^{7}$ On Crete, the practice has only been associated, to date, with the period of Venetian rule

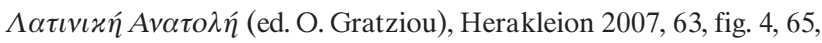
fig. 8, 66, 68, fig. 10, 73, 74, fig. 20, 76, 78, fig. 28, 79 81, 83.

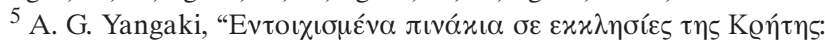

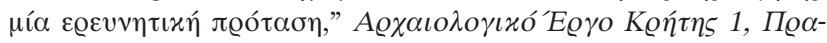

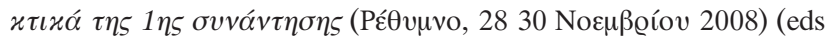
M. Andrianakis I. Tzachili), Rethymnon 2010, 827840.

${ }^{6}$ The data relating to Crete forms part of a major research pro gramme entitled "Immured vessels in churches of Greece: en elec tronic corpus," which seeks to record the bacini in Greece, and which was initiated by the author at the Institute of Historical Research with the collaboration of the respective Ephorates of Byzantine An tiquities. For now, the programme is focused on areas of Attica, the Peloponnese and Crete. Regarding the Prefectures of Rethymnon and Chania, I would like to thank Michalis Andrianakis, now hon orary director of the 28th Ephorate of Byzantine Antiquities, for his willingness to participate in the specific research programme, for granting permission to study the specific practice in respect of churches in both Prefectures, and for his unreserved support throughout the programme. I would also like to thank my colleagues from the 28th Ephorate of Byzantine Antiquities: Natassa Fiolitaki, Athina Fraidaki, Kostas Giapitsoglou, Nikoletta Pyrrou and Petroula Varthalitou for their collaboration and help during the course of the programme.

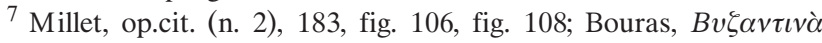

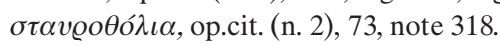




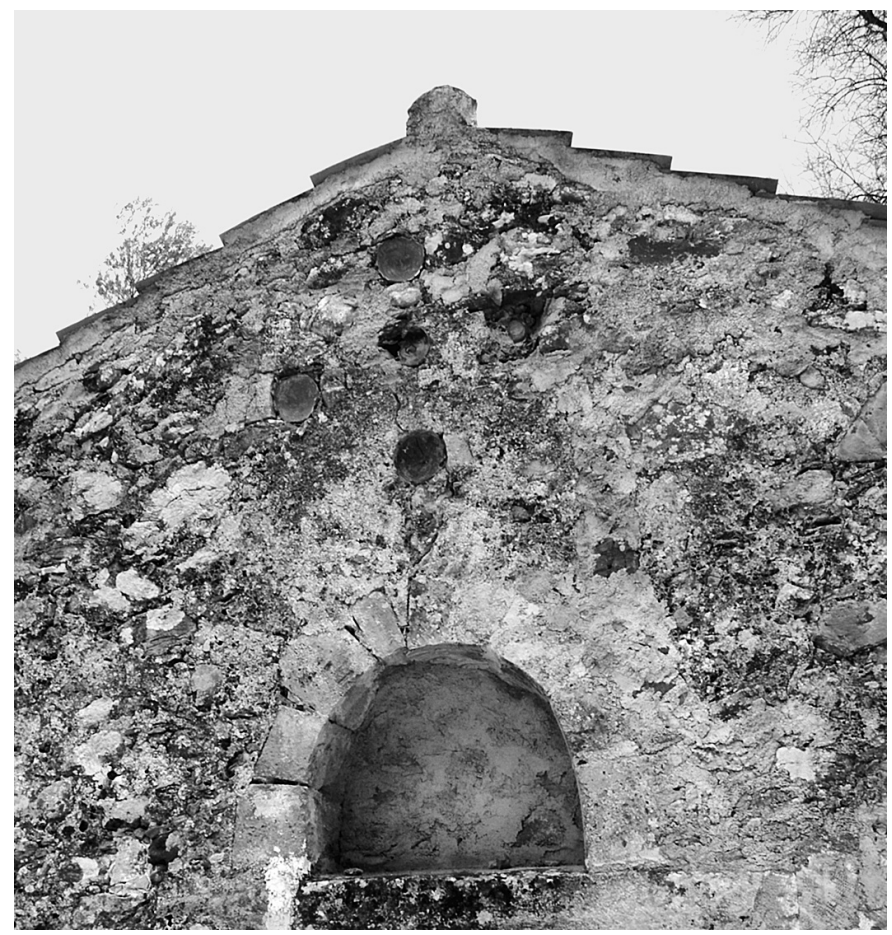

Fig. 1. Nefs-Amari, church of Sts Theodoroi. Immured vessels in cross formation.

and afterwards. One could thus posit that the large number of churches with immured vessels on Crete can be explained by the powerful Italian presence on the island. However, given that the study of vessels immured in churches of the island is still in progress and given the especially large number of churches on Crete, this hypothesis must be made with reservations. The practice makes its first appearance in the area in the 13th century, and is mainly found in churches dating from the 14th and 15th century.

In the Prefecture of Rethymnon, churches with immured vessels are most densely concentrated in the area of the actual municipality of Amari (Table 1). A study of the practice of immuring vessels based on this numerically large sample of churches allows for observations to be made with greater certainty, and confirms the initial data presented in the recent past. ${ }^{8}$ Thus, this form of decoration is mainly found in barrel-vaulted single-cell churches

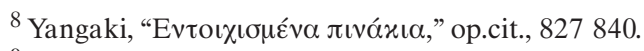

${ }^{9}$ On Crete's barrel vaulted single and two aisled or double churches, see the recent and thorough treatment by O. Gratziou (O. Gratziou,
}

in the area, less frequently in two-aisled churches, ${ }^{9}$ and rarely in churches of other architectural types. In the majority of cases (Fig. 1), a group of five (or, more rarely, four) open vessels are found to be arranged in the form of a cross in the western wall above the entrance and usually above the light-holes, if there are any, at the gable. The position of the vessels is inextricably linked with the location of the entrance; thus, when the entrance is found in the southern rather than the western wall, the vessels are also located in the south-facing wall. The second most common position for immured vessels is in a church's eastern gable, above the apse. In this case, too, the vessels are positioned to form a cross. In roughly $10 \%$ of the cases studied, vessels are found similarly arranged on both the eastern and western wall-faces. No vessels have been found immured in a church's northern facades. We can therefore conclude that the vessels were immured in those sides of the church where they would be visible to the con-

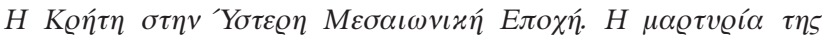

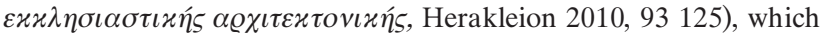
contains the earlier bibliography. 


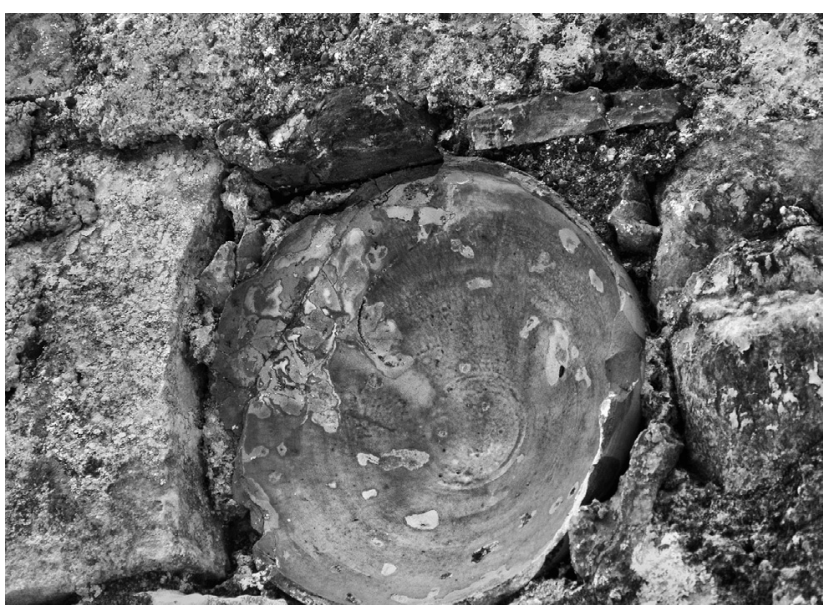

Fig. 2. Nefs-Amari, church of Sts Theodoroi. Detail showing the way the vessel is immured in the wall.

gregation and other visitors, which is to say primarily in the western wall, where most churches have their entrance; sometimes on the southern wall-face to heighten the decorative effect of the façade, usually when the entrance is situated on this side; or on the eastern aspect for decorative reasons, but perhaps also to accentuate the sanctity of this part of the church. Occasionally, the vessels are arranged in a line along the length of the wall, or framing the support arch of the lintel or the lunette. In the majority of cases, the four or five vessels arranged in the shape of the cross are the only ones in the church, and in most churches, there are no more than five vessels. Those rare churches with more than five immured vessels include the katholikon of the Chalepa monastery, the church of St.

\footnotetext{
${ }^{10}$ For the rest of Greece, we refer, by way of illustration, to the range of framing modes found in churches in North western Greece

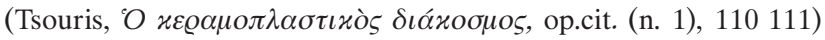

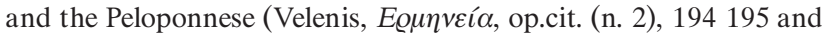
note 1 on p. 195). For churches in Italy, see, for instance: Berti, "Baci ni ceramici e strutture architettoniche," op.cit. (n. 3), 159, fig. 26, 162, fig. 33; O. Mazzucato, "Situazione dei "Bacini" nel Lazio 1993," Atti. XXVI Convegno Internazionale della Ceramica, op.cit. (n. 3), 162 164, 174 175, figs 2d o; G. Berti F. Gabbrielli R. Parenti, "Bacini e architettura. Tecniche di inserimento e complesso decora tive," Atti. XXVI Convegno Internazionale della Ceramica, op.cit. (n. 3), 246 250, 259, fig. 9, 264, fig. 21.

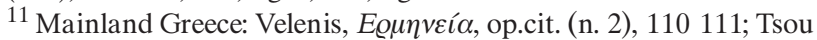
ris, “Glazed Bowls," op.cit. (n. 1), 618; Italy: Mazzucato, op.cit., 174, figs $2 \mathrm{~d}$ e f, 175 , figs $2 \mathrm{~g} \mathrm{~h} 1 \mathrm{~m} \mathrm{n}$.
}

George in Vistagi (Pistagi) and the church of St. George in Opsigias.

Turning to the manner in which the vessels are immured, it would seem, based on the close examination of vessels that have been cleaned and have had newer layers of plaster removed, that the vessels were embedded in specially prepared mortar and rested on stones positioned at the requisite angle. In some cases (Fig. 2), the stones have been carved to match the profile of the vessel which is to rest upon them. The vessels' rims are visible; meaning neither have they been embedded into reinforced mortar applied on top of the masonry, nor has the surrounding masonry been carved in such a way that the rim slots into it. As a rule, therefore, it would not appear that especial care was taken with framing these vessels, as was the case, for example, in churches in mainland Greece or in Italy. ${ }^{10}$ The careful framing of the two vessels (neither of which has survived) in the church of St. Marina in Chalepa is also exceptional in this respect, since they are set in brick circles, which serve to draw attention to them. Frames of this type are found in churches in mainland Greece and in Italy. ${ }^{11}$

The study of the numerous vessels, which have survived in whole or as fragments, has provided data on the fine, glazed wares found on Crete. Most common of all are small and medium-sized bowls with straight rims. There are also large plates. The vessels imported onto the island include some attributed to Byzantine production centres, and others to workshops in the Iberian peninsula, Italy, Syria and Cyprus. Rare examples of Zeuxippus Ware ${ }^{12}$ - category II - number among the earliest types of ceramics found to date, along with more numerous examples (Fig. 3) of Late Sgraffito Ware, bearing simple, incised decor-

\footnotetext{
12 This particular category of pottery is already well documented and continues to attract the attention of researchers. A selection of the core studies would include: A. H. S. Megaw, "Zeuxippus Ware," BSA 63 (1968), 67 87; id., "Zeuxippus Ware Again,” Recherches sur la céramique byzantine (eds V. Déroche J. M. Spieser), BCH Suppl. 18, 1989, 259 266; G. Berti S. Gelichi, "La ceramica bizantina nelle architetture dell'Italia medievale," La ceramica nel mondo bizantino tra XI e XV secolo e i suoi rapporti con l'Italia. Atti del Seminario Certosa di Pontignano (Siena, 1113 marzo 1991) (ed. S. Gelichi), Firenze 1993, 173 174, fig. 34, 179, no. 263, 181, no. 271, fig. $38,1,182$, no. 288 , 183 , fig. 39,185 , no. 98 , fig. 43 , 186, fig. 45 ; Y. Waksman V. François, "Vers une redéfinition typologique et analy tique des céramiques byzantines du type Zeuxippus Ware," $B C H$ 128129 (2004 2005), 629724.
} 


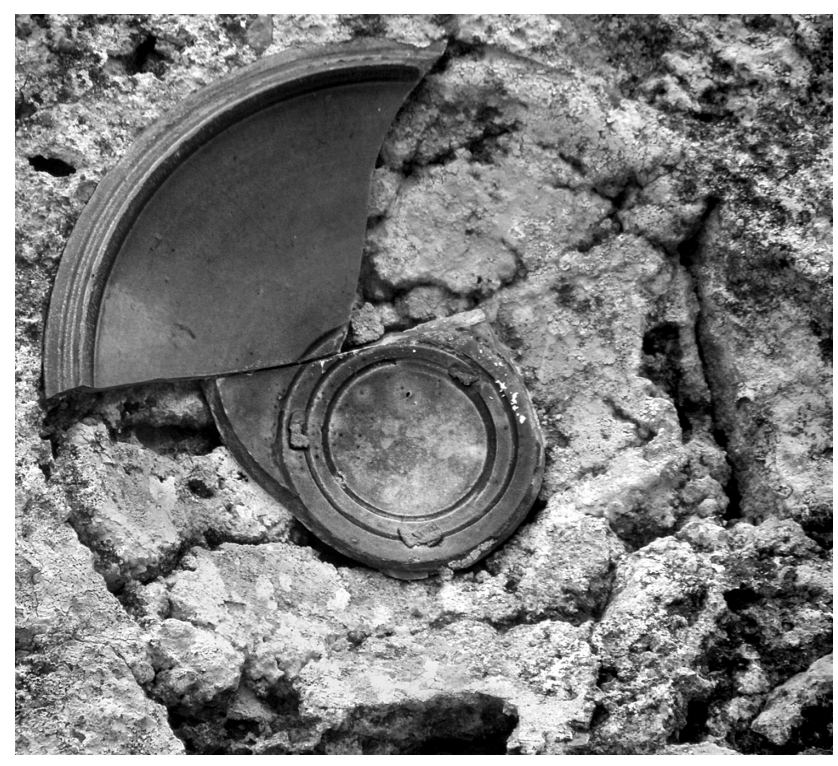

Fig. 3. Voliones, Afentis Christos. Immured Late Sgraffito Ware plate.

ation covered with dark orange or green glaze, considered to be related to the Zeuxippus Ware Family. ${ }^{13}$ The lateByzantine ceramics workshops are represented by a few examples of incised vessels (Fig. 4) which could be attributed to the production of workshops in Thessalonike. ${ }^{14}$

\footnotetext{
${ }^{13}$ For the use of the term Late Sgraffito Ware, see: G. D. R. Sanders, "Excavations at Sparta: The Roman Stoa, 1988 1991. Preliminary Report. Part I (c) Medieval Pottery," BSA 88 (1993), 257, and J. Vroom, After Antiquity. Ceramics and Society in the Aegean from the 7th to the 20th Century A.C. A Case Study from Boeotia, Central

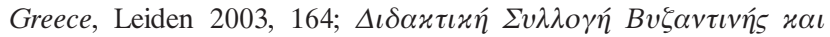

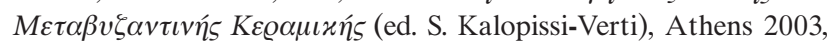
89. Late Sgraffito Ware comprises mostly pottery bearing character istics similar to those of the so called sub categories Ib and Ic of Zeuxippus Ware, which recent research does not connect to the prototype production of Zeuxippus Ware (see, in detail: Waksman François, op.cit., 629 724).

${ }^{14}$ On glazed pottery attributed to workshops in Thessalonike, see: Ch. Bakirtzis D. Papanikola Bakirtzis, "De la céramique byzantine en glaçure à Thessalonique," Byzantinobulgarica 7 (1981), 434 436,

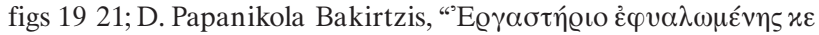

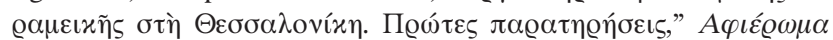

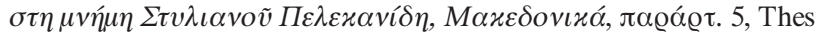
salonike 1983, 377 387; ead., "The Palaeologan Glazed Pottery of Thessaloniki," L'art de Thessalonique et des Pays Balkaniques et les courants spirituels au XIV siècle, Recueil des rapports du IVe colloque serbo-grec (Belgrade 1985) (ed. R. Samardžić), Beograd 1987,

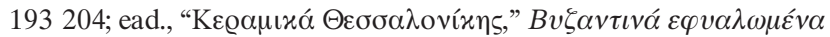

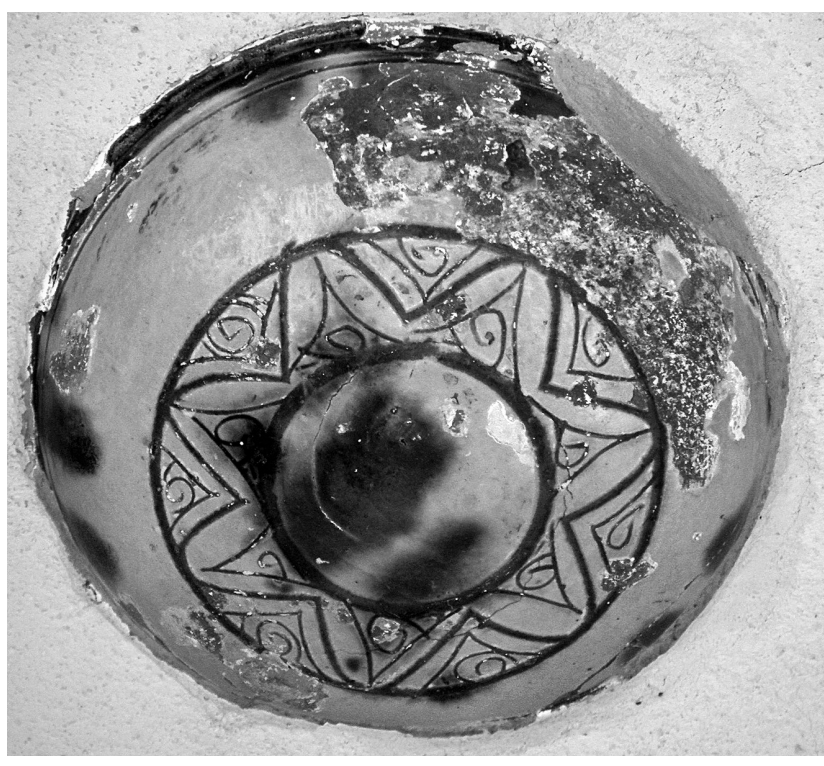

Fig. 4. Agia Trapeza (Kalandare). Immured sgraffito bowl attributed to Thessalonike workshops.

Monochrome-blue and lustreware pottery (Fig. 5) of the production centres of the Valencia region, in the Iberian peninsula, dating from the late 14 th and the 15 th centuries, ${ }^{15}$ together with Syrian pottery painted in black, blue and turquoise (Fig. 6), dating from mainly after the

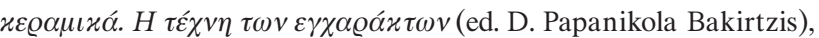

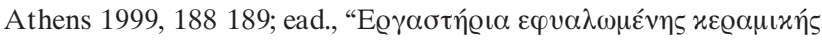

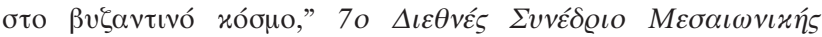

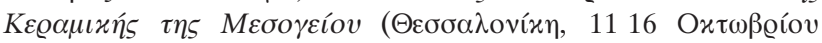

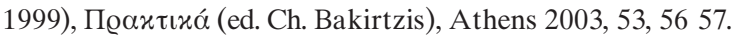

15 On these two categories of pottery from the Iberian peninsula: B. Martínez Caviró, La loza dorada, Madrid 1982, 101 103, 111 169; J. Martí, "An Overview of Medieval Pottery Production in Spain be tween the Thirteenth and the Fifteenth Centuries," Medieval Ceramics 18(1994), 5, fig. 1; M. Paz Soler, "Cerámica Valenciana," Summa Artis, Historia General del Arte, vol. XLII, Cerámica Española (ed. T. Sánchez Pacheco et al.), Madrid 1997, 137 166; A. Ray, Spanish Pottery 1248-1898. With a Catalogue of the Collection in the Victoria and Albert Museum, London 2000, 41 102; J. Rose Al brecht, "Valence," Le calife le prince et le potier, les faïences à reflets métalliques (Lyon, musée des Beaux Arts 2 mars 22 mai 2002) (ed. J. Rose Albrecht), Paris 2002, 76. For a first reference to pottery from the Iberian peninsula in Crete, see: A. G. Yangaki, "Ave Maria Gra[tia] Plena: A Spanish Lustreware plate from the church of Pana

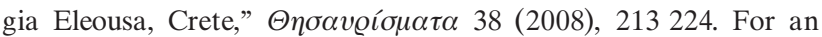
overview on Late Mediaeval pottery from the Iberian peninsula in Greece: ead., "A First Overview on Late Medieval Pottery from the Iberian Peninsula in Greece,” Viator 44.1 (2013), 287326. 


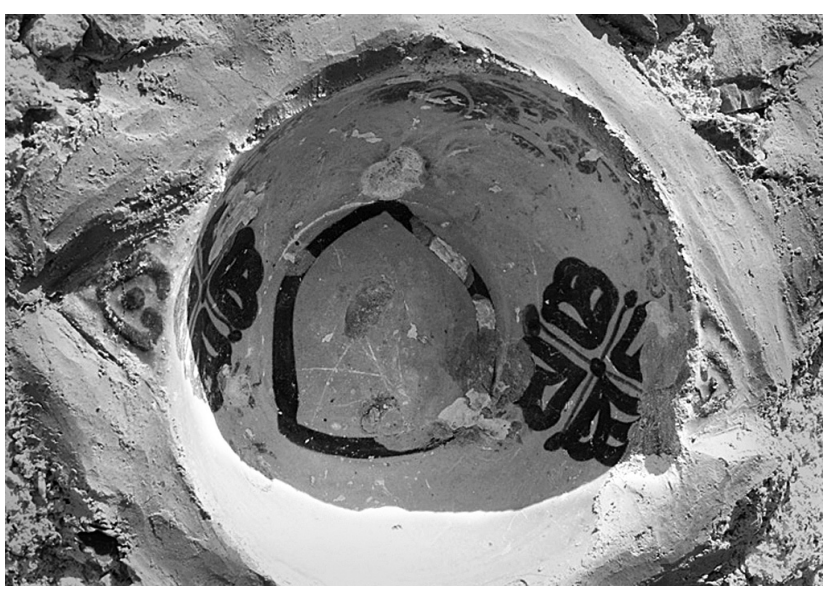

Fig. 5. Katholikon of the monastery at Chalepa. Immured lustreware bowl.

1st half of the 14th and from the 15 th century, ${ }^{16}$ and incised pottery from Cyprus, dated to the 13th-14th centuries, ${ }^{17}$ are represented by a limited number of richly decorated vessels. However, the bulk of the ceramics imported into Crete - much of which was incised - were from centres in Italy. The "San Bartolo" type, which is attri-

\footnotetext{
16 A. Lane, Later Islamic Pottery. Persia, Syria, Egypt, Turkey, Lon don 1957, 15 20, 29 30; J. Soustiel, La céramique islamique. Le guide du connaisseur, Fribourg 1985, 223 224; E. J. Grube, Islamic Pottery of the Eighth to the Fifteenth Century in the Keir Collection, London 1976, 292; G. Fehérvári, Pottery of the Islamic World in the Tareq Rajab Museum, Kuwait 1998, 50; G. Fehérvári, Ceramics of the Islamic World in the Tareq Rajab Museum, London, New York 2000, 246, 251; O. Watson, Ceramics from Islamic Lands, London 2004, 5458.

${ }^{17}$ For the main centres of pottery production on Cyprus during the Medieval period, and the most characteristic categories of Cypriot

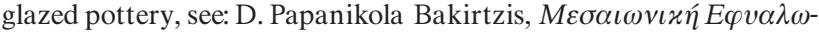

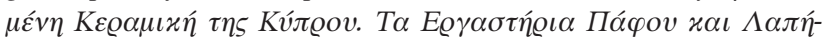
$\theta$ ov, Thessalonike 1996. For pottery of the 13th century with simple,

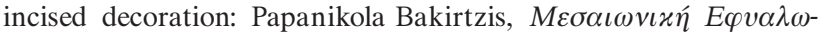

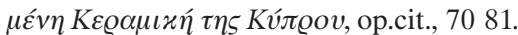

${ }^{18}$ S. Gelichi, "Roulette Ware," Medieval Ceramics 8 (1984), 52, fig. 6, 54, fig. 7, fig. 8, 55; id., "La ceramica ingubbiata medievale nell'I talia nord orientale," La ceramica medievale nel mediterraneo occidentale (Siena 812 ottobre 1984, Faenza 13 ottobre 1984), Firenze 1986, 367 369, 370, 371, 387 388; id., "La ceramica bizantina in Italia e la ceramica italiana nel Mediterraneo orientale tra XII e XIII secolo: stato degli studi e proposte di ricerca," La ceramica nel mondo Bizantino tra XI e XV secolo, op.cit. (n. 3), 25; F. Saccardo, "Contesti medievali nella laguna e prime produzioni graffite veneziane," ibid., 214232.
}

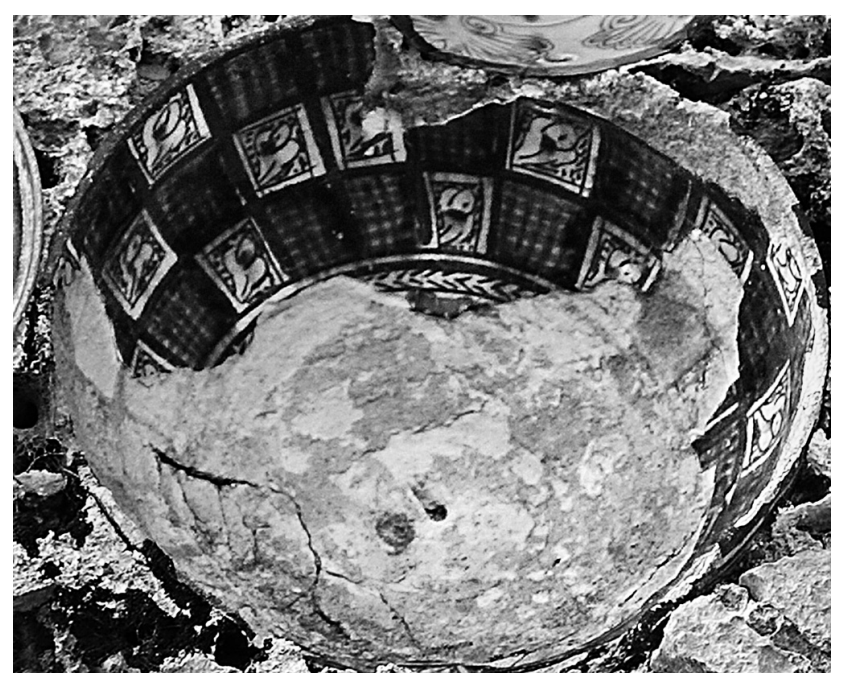

Fig. 6. Prinos, church of Zoodochos Pigi. Immured large plate from Syria, painted in black and blue.

buted to workshops in Venice and dates from the latter half of the 13th and the 14th centuries, ${ }^{18}$ accounts for some of the earliest Italian ceramics found in the area. The examples of Italian "graffita arcaica"19 (Fig. 7) and the Italian incised polychrome pottery of the Renaissance ("graffita rinascimentale canonica") ${ }^{20}$ (Fig. 8), which

\footnotetext{
19 This widespread category of pottery was produced in various parts of the Italian peninsula and is divided into two major sub cate gories: "graffita arcaica padana" and "graffita arcaica tirrenica" (D. Whitehouse, "Medieval Pottery in Italy: the Present State of Re search," La céramique médiévale en Méditérranée occidentale, XeXVe siècles (Valbonne 1114 Septembre 1978), Paris 1980, 75 77; H. Blake, "The Medieval Incised Slipped Pottery of North West Italy," La ceramica medievale nel mediterraneo occidentale, op.cit., 316 348; S. Gelichi, "La ceramica graffita in Emilia Romagna," San Giovanni in Persiceto e la ceramica graffita in Emilia-Romagna nel '500 (ed. S. Gelichi), Firenze 1986, 24 27; id., "La ceramica ingubbia ta medievale," op.cit., 388 403; M. Munarini, "Caratteri generali. Il Veneto centrale e Concordia Sagittaria," La ceramica nel Veneto, La Terraferma dal XIII al XVIII secolo (eds G. Ericani P. Marini), Verona 1990, 32 41; C. Varaldo, "La graffita arcaica tirrenica," La céramique médiévale en Méditerranée. Actes du VIe congrès de l'AIECM2 (Aix en Provence, 1318 novembre 1995) (ed. G. Dé mians d'Archimbaud), Aix en Provence 1997, 439451.

${ }^{20}$ Gelichi, "La ceramica graffita in Emilia Romagna," op.cit., 28 33; M. Munarini, "Graffita Rinascimentale Canonica,” La ceramica nel Veneto, op.cit., 78 79; M. Munarini, "La raccolta di ceramiche ri nascimentali dei Musei Civici di Padova," Ceramiche Rinascimentali dei Musei Civici di Padova (Padova, Museo Civico di piazza del Santo 11 dicembre 199330 aprile 1994) (eds M. Munarini D. Ban zato), Milano 1993, 28 32, 3435.
} 


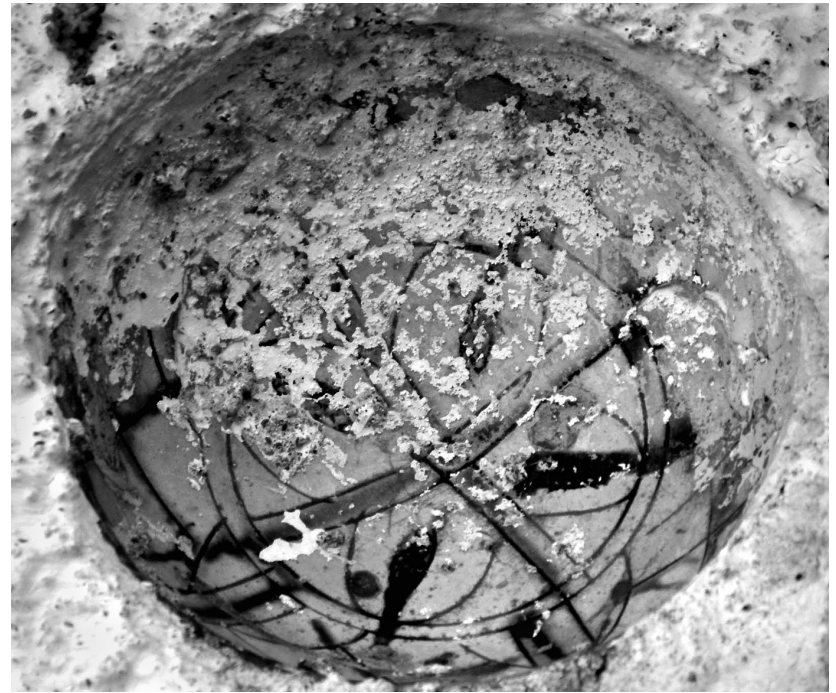

Fig. 7. Chordaki, church of Panagia Faneromeni. Immured graffita arcaica bowl.

stands out for its rich and especially well executed decoration, are highly typical of the Italian ceramics found on Crete. Painted Italian pottery is limited to examples of "polychrome glazed pottery" (Fig. 9) with a lead glaze ("RMR Ware"). ${ }^{21}$ Other common categories of ceramics include monochrome glazed pottery covered with a dark - usually brown, and particularly glossy - glaze, ${ }^{22}$ and vessels whose slip-painted decoration comes in the form of simple, broad, thick bands. This form of decoration is a continuation of that found in a category of pottery which

\footnotetext{
${ }^{21}$ For the characteristics of this production and its diffusion around the Mediterranean, see: D. Whitehouse, "Proto Maiolica," Faenza 66 (1980), 82 83; D. Dufournier A. M. Flambard G. Noyé, "À pro pos de céramique 'RMR': problèmes de définition et de classement, problèmes de répartition," La ceramica medievale nel mediterraneo occidentale, op.cit., 250 277; D. Whitehouse, "Apulia," ibid., 579; P. Tagliente, "La ceramica invetriata policroma nel basso Salento," La ceramica invetriata tardomedievale dell'Italia Centro-Meridionale (ed. St. Patitucci Uggeri), Firenze 2000, 167181.

22 On similarly decorated objects produced in Italian workshops, see: D. Pringle, "La ceramica dell'area Sud del Convento di S. Silve stro a Genova," Archeologia Medievale 4 (1977), 116 117, 120; F. Cozza, La produzione ceramica veneta dal basso Medioevo al Rinascimento. Classi ceramiche, tipologie degli ornati e aspetti di cultura materiale, Padova 1989, 19; M. Munarini, "La produzione più antica," La ceramica nel Veneto, op.cit. (n. 19), 19 23; G. Ericani, "Invetriata e graffita arcaica nel Veneto orientale e meridionale,"
}

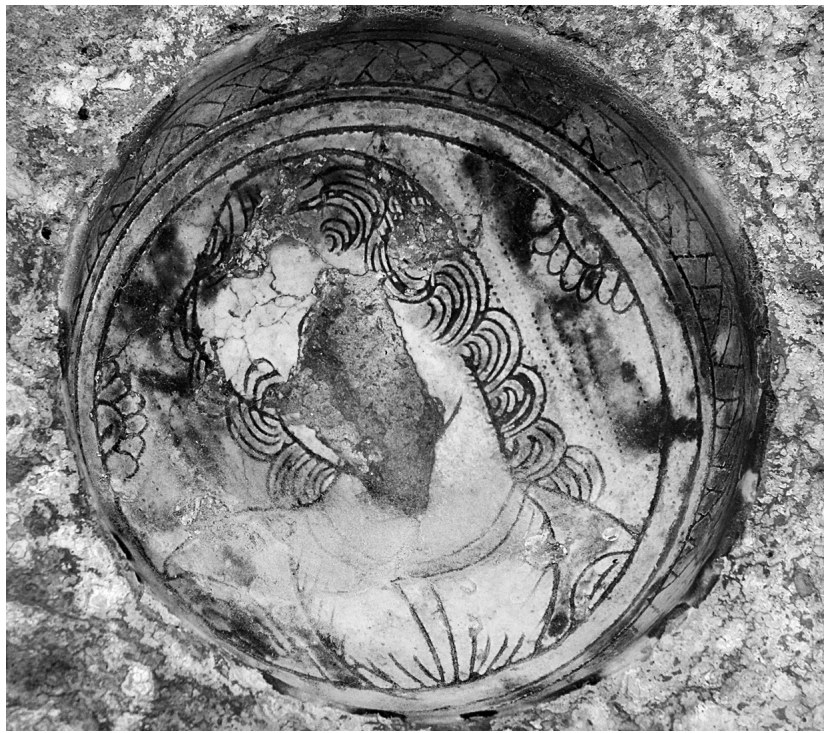

Fig. 8. Platanos, church of St. Antonios. Immured "graffita rinascimentale canonica" bowl.

was especially widespread during the mid-Byzantine period, ${ }^{23}$ although the later, slip-painted category ${ }^{24}$ differs from this earlier category in that its slip is applied to the surface in a deliberately slap-dash way.

Additional processing of the sample in question will clearly contribute to our knowledge of various aspects of bacini practice. For instance, limiting ourselves to a superficial account of two of these, researchers have noted that the study of churches with immured vessels in other areas has provided additional data on the dating of at least the sec-

ibid., 50 51. On similar objects from Herakleion attributed to Italian

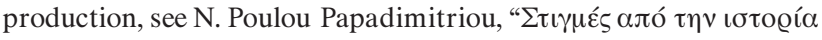

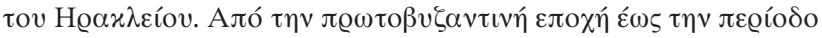

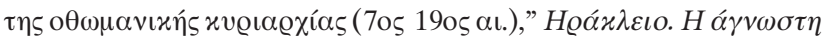

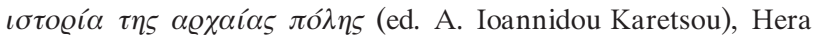
kleion 2008, 185, figs 4445.

${ }^{23}$ Ch. H. Morgan, II, Corinth XI, The Byzantine Pottery, Cambridge,

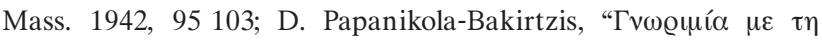

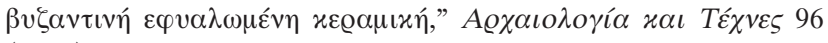
(2005), 28.

${ }^{24}$ On the characteristics of this category, see J. Vroom, Byzantine to Modern Pottery in the Aegean. 7th to 20th Century. An Introduction and Field Guide, Utrecht 2005, 153; A. K. Vionis, "The Archaeology of Ottoman Villages in Central Greece. Ceramics, Housing and Everyday Life in Post Medieval Boeotia," Studies in Honor of Hayat Erkanal: Cultural Reflections (ed. B. Avunç), Istanbul 2006, 790. 


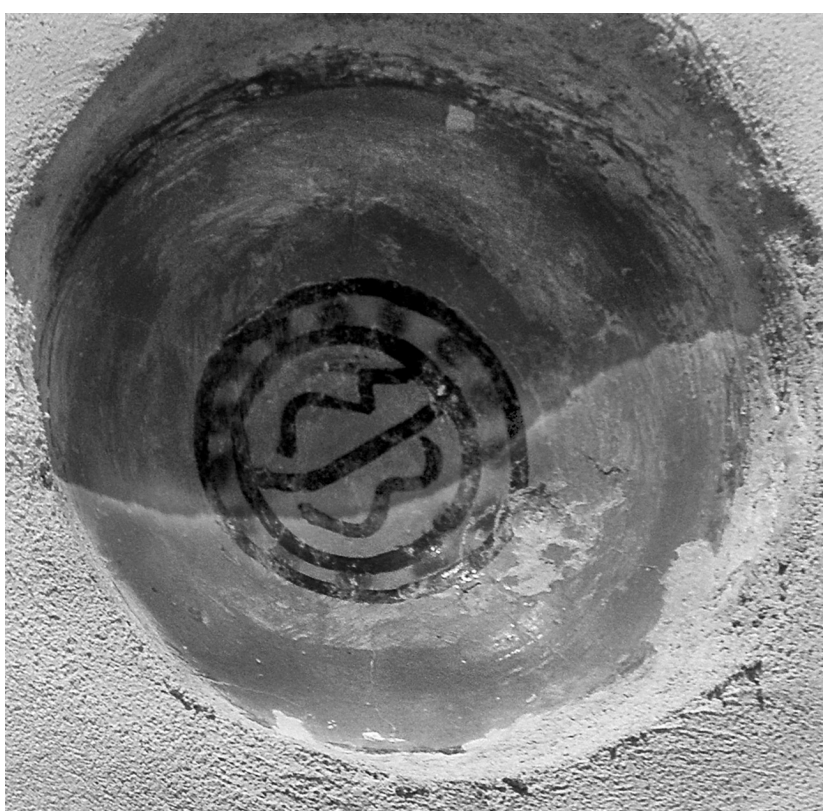

Fig. 9. Garazo, church of the Dormition of the Virgin. An example of an immured RMR Ware bowl.

tion of wall in which they were immured, ${ }^{25}$ if not the monument as a whole. ${ }^{26}$ This appears to largely hold true on Crete, too, since churches in the Prefecture of Rethymnon built in different periods are indeed adorned with different categories of ceramics, while similar types of ceramics are encountered in churches built during much the same period. For example, in the Amari region, examples of Late Sgraffito Ware (see above) have been found in the churches of St. Georgios in Opsigias, Afentis Christos in Voliones, and Sts Theodoroi in Amari itself, all of which date from the 13th or 14th century. Furthermore, in the Mylopotamos area, four churches built between the mid14th and early 15th century are adorned with examples of RMR Ware. As the systematic recording of the data proceeds further, it should be possible to create sub-categories of churches which are decorated with the same types of ceramics, and which can probably be grouped together on the basis of their architecture and their architectural and painted decoration.

The research programme may also shed light on differences in the practices relating to the immuring of vessels in monastic institutions, on the one hand, and in churches not associated with a monastery, on the other. The data that has emerged from the area in question would indicate that this form of decoration is more common in churches unattached to monasteries. However, in those rare cases where katholika were decorated with bacini, usually their number was not limited to the usual four or five ceramics, as in churches unattached to monasteries, but the vessels were more numerous and they belonged to high-quality productions. For example, the practice is only encountered in four of the numerous monasteries in the Prefecture of Rethymnon which date from the period of Venetian rule and in two of the four instances - in the church of the Zoodochos Pigi at Prinos and the katholikon of Chalepa monastery - extremely fine, imported ceramics were used as bacini. A comparison between these monasteries and monasteries in the Herakleion region - where, once again, only very few of the numerous katholika were adorned with vessels - allows us to conclude that here, too, the immured vessels were, in each case, both of extremely good quality and more numerous than those immured in churches unattached to monasteries. The large number of vessels immured in katholika, the use of ceramics from the Iberian peninsula, Italy and Syria - examples from the first two of which were expensive and have only been found in katholika to date - and the fact that the vessels were not usually arranged in a particular pattern raise questions as to whether the choice of a particular type of ceramics was random or prompted by specific considerations, thus probably serving, a symbolic role in addition to a decorative one.

\footnotetext{
${ }^{25}$ Berti, "Bacini ceramici e strutture architettoniche," op.cit. (n. 3), 137; L. Castelletti, "L'inserimento di ceramiche nell'architettura. Il caso della chiesa di San Romano a Lucca," Archeologia Medievale 21 (1994), 193.

${ }^{26}$ S. Gelichi, "Ceramiche venete importate in Emilia Romagna tra XIII e XIV secolo," Padusa 24 (1988), 7; Berti, "Bacini ceramici e strutture architettoniche," op.cit. (n. 3), 137 and 137 140; ead., "Problematiche," op.cit. (n. 4), 12 14. For related opinions regarding the dating of monuments with immured vessels in Greece: A. H. S.
}

Megaw, "The Chronology of Some Middle Byzantine Churches," BSA 32 (1931 1932), 90 130; id., "Glazed Bowls in Byzantine Churches," $\triangle X A E \Delta^{\prime}, 4$ (1964 1965), 145 162; Nikolakopoulos,

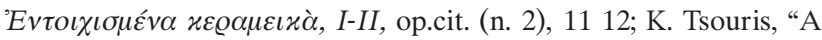
Bowl Embedded in the Wall of the Chapel of the Hagioi Anargyroi in Vatopedi Monastery," BalkSt 39 (1998), 1011 (where it is noted that even if immured vessels cannot offer an absolute dating for a church, they offer evidence for its relative dating). 
It is thus clear that there are many additional aspects of bacini to be studied relating to the history of the area and the architecture of the churches in which they are found, and to the types of ceramics immured. One of the more interesting aspects of bacini relates to the study of Mediaeval pottery on the island. As we now know, most of the bacini on Crete were imported from various Mediterranean regions, and most commonly from Italy. Since only a limited number of publications have concerned themselves with these categories of pottery found on the island, ${ }^{27}$ studying bacini could enhance our knowledge of Mediaeval glazed pottery.

\section{Municipality Number of Churches}

$\begin{array}{lc}\text { Rethymnon } & 8 \\ \text { Mylopotamos } & 19 \\ \text { Anogeia } & 2 \\ \text { Amari } & 25 \\ \text { St. Vasilios } & 20\end{array}$

Table 1. Distribution of churches with immured vessels in the Prefecture of Rethymnon.

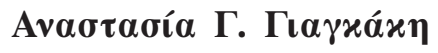

\section{ENTOIXI $\Sigma$ MENA AГГEIA $\Sigma$ E EKK $\Lambda \mathrm{H} \Sigma \mathrm{IE} \Sigma \mathrm{TH} \Sigma$ KPHTH $\Sigma$ :

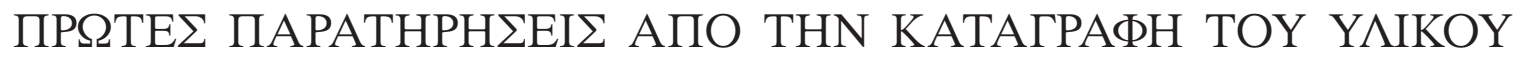 $\Sigma$ THN ПEPIOXH TOY NOMOY PE@YMNOY}

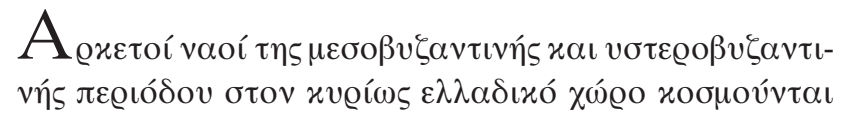

${ }^{27}$ We mention, for example, the publications of pottery from Chania

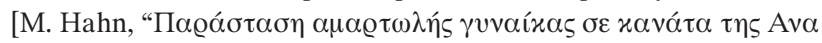

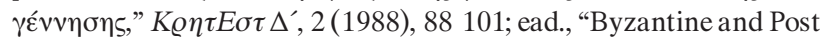
byzantine Pottery from the Greek Swedish Excavations at Khania, Crete," Recherches sur la céramique byzantine, op.cit. (n. 12), 232, figs 8, 9, 10, 13; ead., "A Group of 15th/16th Century Jugs from Western Crete," Recent Danish Reseach in Classical Archaeology: Tradition and Renewal, Danish Studies in Classical Archaeology (eds T. Fischer Hansen P. Guldager J. Lund M. Nielsen A. Rathje),

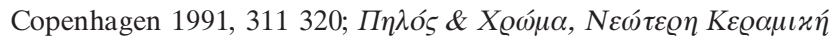

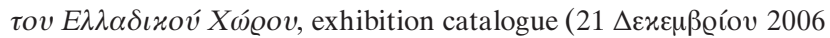

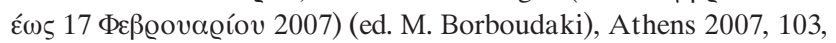
cat. no. 62 (A. Apostolaki), 104, cat. no. 63(A. Apostolaki), 105, cat. no. 64 (A. Apostolaki), 106 107, cat. no. 65 (A. Apostolaki), 108, cat. no. 66 (K. Psarakis), 114, cat. no. 72 (A. Apostolaki), 117, cat. no. 75 (K. Psarakis), 118, cat. no. 76 (K. Psarakis)], from Pyrgi at

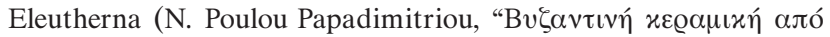

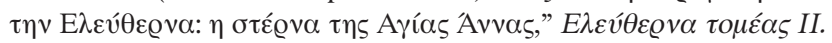

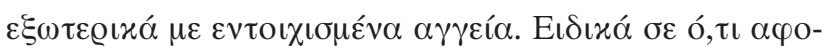

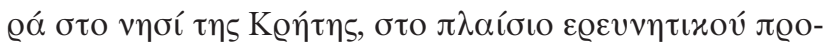

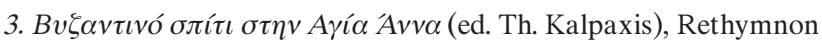

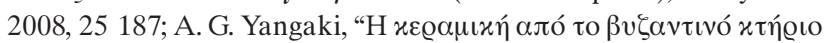

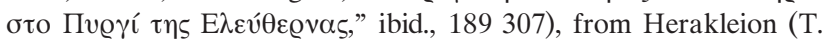
Stillwell MacKay, "A Group of Renaissance Pottery from Heraklion, Crete: Notes and Questions," The Archaeology of Medieval Greece (eds P. Lock G. D. R. Sanders), Oxford 1996, 127 137; Poulou Pa

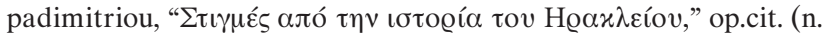

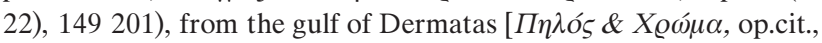
115, cat. no. 73 (Ch. Samiou), 116, cat. no. 74 (Ch. Samiou)], from Agia Triada (V. La Rosa, "Il cimitero veneziano di Haghia Triada," Creta Antica 2(2001), 250 251, figs 22 24, 252 253, figs 35, 267, figs 73 74), from Amnisos (E. Stefanaki, "Areal J: Die venezianische Keramik," Amnisos, nach den Archäologischen, Historischen und Epigraphischen Zeugnissen des Altertums und der Neuzeit (ed. J. Schäfer), Berlin 1992, 274 282), from Malia (V. François, "La céramique à glaçure à Malia: productions médiévales italiennes et productions ottomanes," BCH 118 (1994), 376 380, figs 2, 3). 


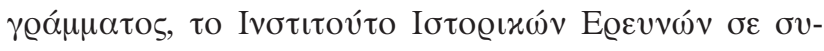

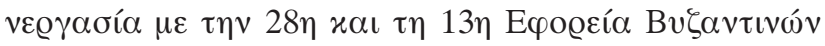

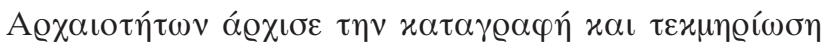

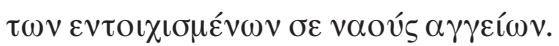

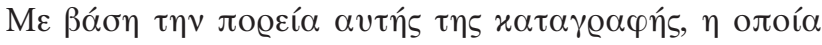

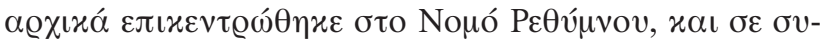

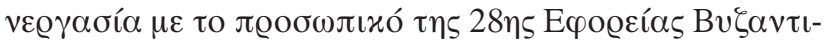

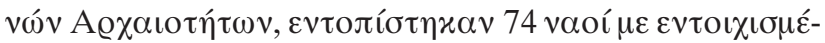

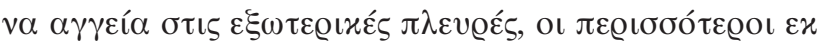
$\tau \omega v$ олоí

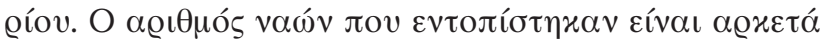
$\mu \varepsilon \gamma \alpha \dot{\lambda} \mathrm{o \zeta ,} \mathrm{\sigma \varepsilon} \mathrm{\sigma \chi \varepsilon ́ \sigma \eta} \mathrm{\mu \varepsilon} \mathrm{\tau ov \varsigma} \mathrm{v \alpha oú \varsigma} \mathrm{\pi ov} \mathrm{\varepsilon ́ \chi ovv} \mathrm{\varepsilon v \tau олเ \sigma \tau \varepsilon í}$

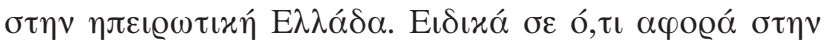

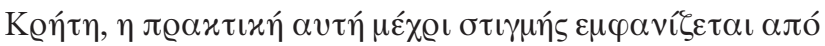

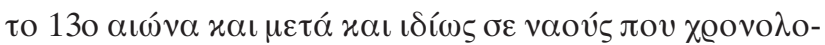

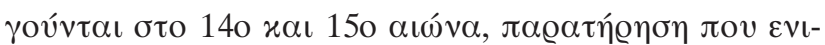

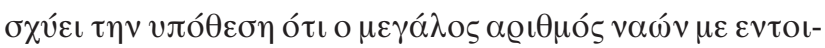

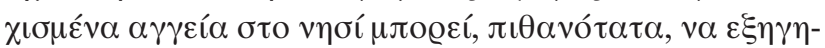

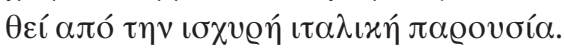

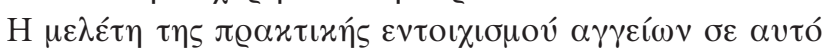

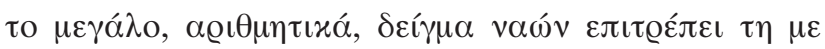
$\mu \varepsilon \gamma \alpha \lambda \hat{\tau} \tau \varrho \eta \eta$

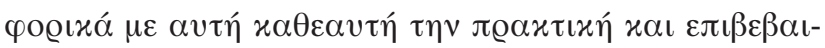

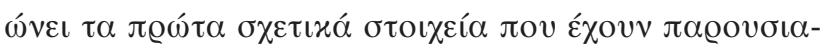

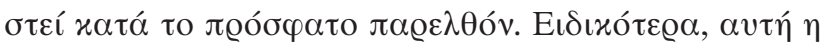

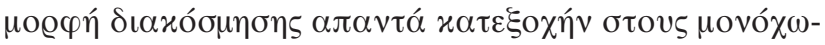

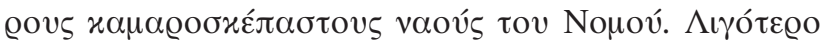

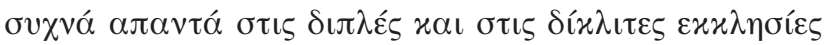

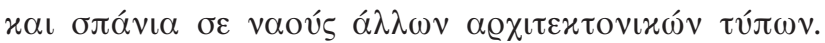

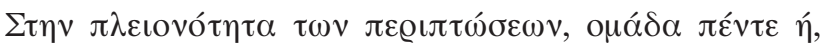

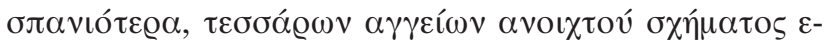

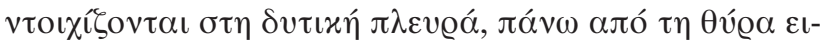

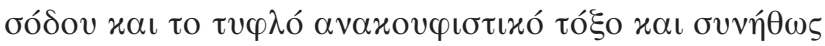

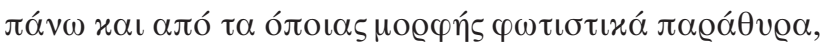

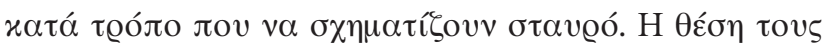

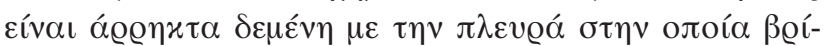

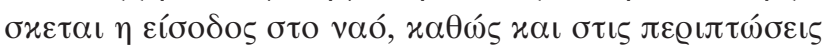

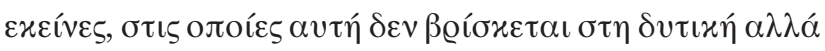

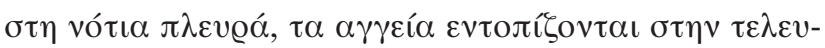

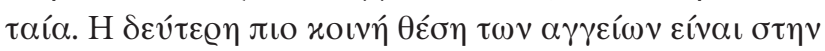

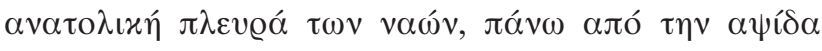

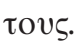

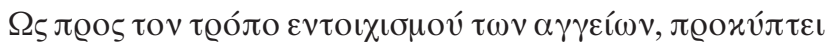

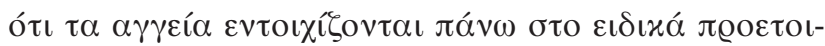

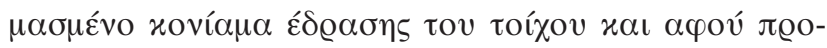

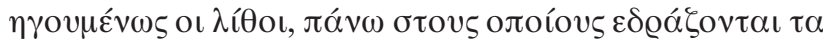

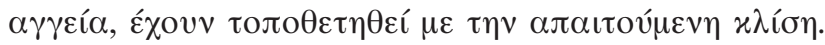

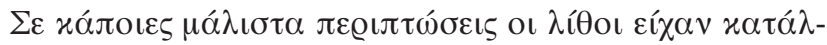

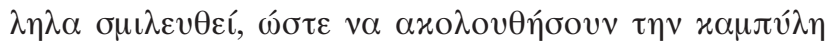

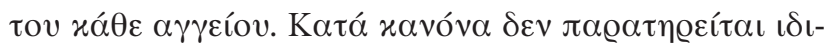

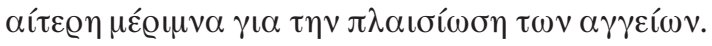

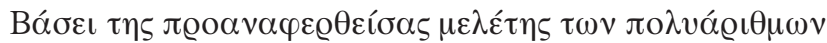

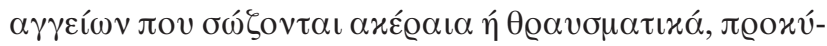

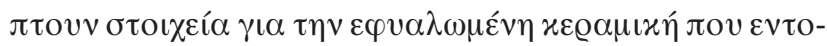

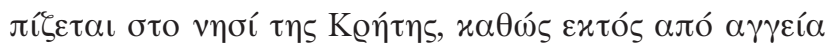

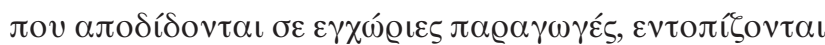

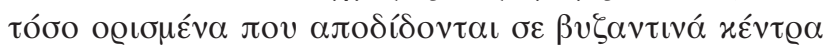

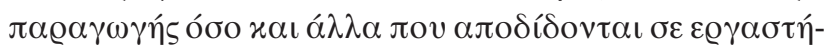

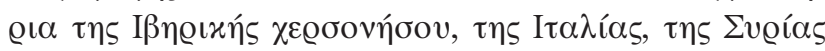

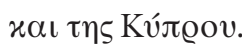

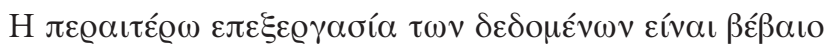

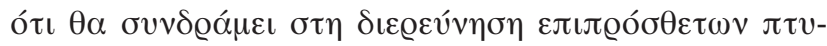

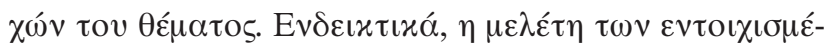

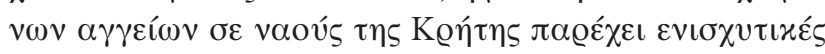

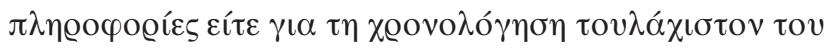

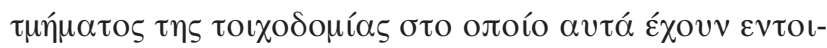

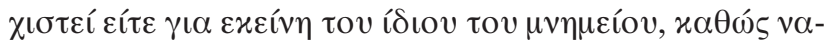

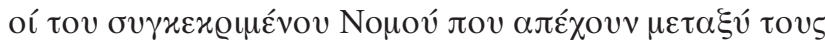

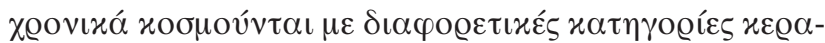

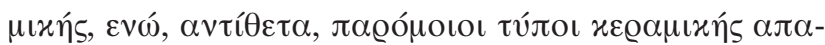

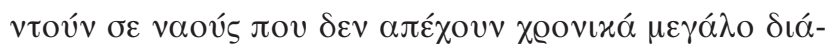

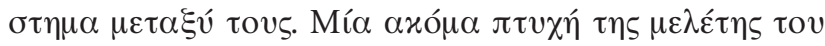

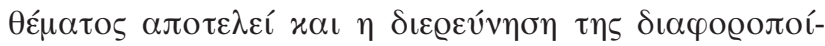

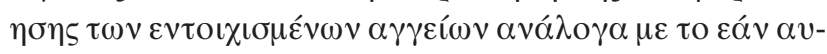

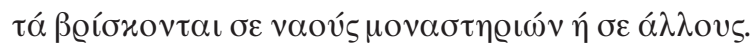

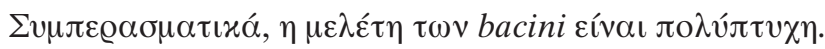

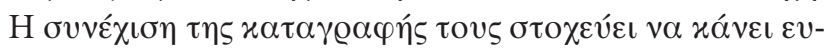

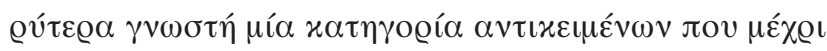

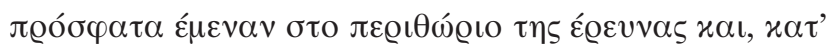

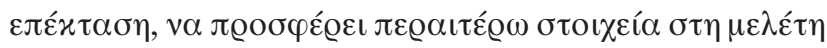

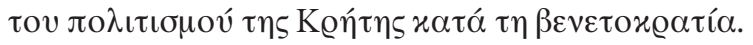

